\title{
Framing Open Innovation in Start-Ups' Incubators: A Complexity Theory Perspective
}

\author{
Cinzia Battistella ${ }^{1}$, Alberto F. De Toni ${ }^{2}$ and Elena Pessot ${ }^{2, *}$ \\ 1 Department of Information Engineering and Mathematical Sciences, University of Siena, 53100 Siena, Italy; \\ cinzia.battistella@unisi.it \\ 2 Polytechnic Department of Engineering and Architecture, University of Udine, 33100 Udine, Italy; \\ alberto.detoni@uniud.it \\ * Correspondence: elena.pessot@uniud.it; Tel.: +39-0432-558-043
}

Received: 15 June 2018; Accepted: 3 August 2018; Published: 7 August 2018

\begin{abstract}
Recently, concepts and principles from the Complexity Theory (or, generally speaking, the complexity sciences) have been applied as a perspective for capturing the influence of the context, interaction, and adaption in the innovation processes, such as the ones enabled in the business incubators. The purpose of this paper is to implement a frame of reference for understanding the start-ups' incubator as a complex system where innovation, learning, and self-organization take place. We build on the interfaces between the Complexity Theory (i.e., complexity sciences) and Open Innovation literature to identify principles, patterns, and conditions that frame the incubation practices as simple rules aimed to sustain the innovation process towards the creation of new ventures. Results from the multiple case studies conducted in five incubators show that the features of variety, nonlinear interaction, interdependence, autonomy, and emergence of the incubation process framed as a complex system are enabled in different ways by the combination of the open innovation practices and services provided by the start-ups' incubators, including the provision of physical infrastructure, access to funding streams, experts/entrepreneurs networking, education/workshops, mentorship, and advice.
\end{abstract}

Keywords: open innovation; business incubator; complexity sciences; practices; case study

\section{Introduction}

Concepts and principles from the Complexity Theory (or, generally speaking, the complexity sciences) have been widely adopted to understand the interactions and dynamics that characterize organizations and business networks. Recent studies applied the complexity lens as a perspective for exploring and capturing the conditions that enable the emergence of innovation processes in firms.

For example, complexity science has been adopted as a new approach for studying the innovation processes in industrial districts [1], representing the emergence of social innovation and its many differences [2], analyzing the creativity emergent process [3]. Indeed, "innovation, by its very nature, involves the unprecedented, the unpredictable, and the non-deducible with respect to current circumstances" [2], reflecting some of the key features of complex systems.

This is true also for the context of Open Innovation. Indeed, a diffuse topic of investigation through complexity lens is the mechanisms and approaches adopted in opening up the innovation process to establish one or more relationships with external actors, such as in open innovation networks [4] and ecosystems [5]. Among the possible mechanisms, the incubation and venturing process has a key role in offering supportive environments for sustaining the growth of new ventures and then bring innovations to the market [6,7]. The value proposition of the business incubators [8] includes basic services such as the offering of facilities and services shared among the tenant start-ups, mentoring, 
coaching, and access to external sources of innovation through institutionalized networks to guide the entrepreneurial teams through their development process. In their recent literature review, Hausberg and Korreck [9] argue that a promising research direction is the adoption of open innovation as a perspective to understand the incubators and their innovation environment. Previous contributions have mainly focused on the study of the practices and services offered by the incubators from the perspective of their value offer [8] or the model adopted in running their business [10].

This paper aims to analyze the context of business incubators as a process of innovation emerging from the interdependence of autonomous agents which interact in different, nonlinear ways with other sources of knowledge to stimulate the growth of new ventures. We build on the interfaces between the Complexity Theory (i.e., complexity sciences) and Open Innovation literature to identify principles, patterns, and conditions that frame the incubation practices as simple rules aimed to sustain the innovation process carried out by the tenant start-ups. Aiming to a deeper understanding of the micro-level foundations of the innovation processes that leverage on both internal and external sources of knowledge across the boundaries of a start-ups' incubator, we formulated the research question as follows:

RQ: How can business incubators related practices enable an emergent open innovation environment from a complexity theory perspective?

\section{Theoretical Background}

\subsection{Open Innovation and Complexity Theory}

Nowadays, companies need to select the mechanisms and behaviors to be most beneficial in engendering a continuous innovation process while dealing with the increasing complexity on a day-by-day basis $[4,11]$. Businesses are required to innovate and evolve in an ecosystem that is increasingly complex [5,12], with new, comprehensive approaches.

In this sense, complexity thinking represents a key perspective for a deeper understanding of innovation [13], especially after the introduction of the 'network' as a key unit for analyzing the innovation process beyond an organization' boundaries [14]. The innovation network of a company embraces heterogeneous and autonomous agents such as competitors, suppliers, customers, research centers, and other public institutions that interact pursuing the common goal of developing, exploiting, or commercializing an innovation [1,4]. In this sense, the properties of complex adaptive systems are adopted as perspective to study the features of the innovation ecosystems [15] and the industrial districts [1], characterized by a complex network of interorganizational relations.

In their literature review, Poutanen et al. [16] identify the complexity themes addressed in the innovation literature, and specifically in the publications focusing on the Open Innovation paradigm. They argue that the micro-level foundations of the innovation process include the interactions, the relationship formation, and the knowledge creation among multiple different players. These interactions are nonlinear as to favor dynamics deriving from communication and feedback flows [12]. Indeed, open innovation is characterized by the involvement of different innovation actors, the formation of multifaceted interorganizational relationships between them, the paths inside and outside an organization's boundaries to access the distributed knowledge [4]. Moreover, innovation results in the emergence of networks of innovation that are distributed, self-organized, and integrating internal flexibility with a high variety of resources and diversity of capabilities [14]. In this sense, an ecosystem view of innovation as a system of actors requires to consider it as an initiative that may not have been planned, but emerging from the interactions among actors within the broader system [12]. The adoption of the complexity lens aims then to capture the evolving patterns that derive from the interaction between the innovation actors, in addition to their features and the type of interrelationships between them.

The structures and dynamics deriving from leveraging on different actors as sources of innovation can be framed as emergent phenomena resulting from the local choices of the different actors [1]. 
Measuring effectively the performance resulting from the adoption of open innovation is still difficult, also due to the unintended or unforeseen outcomes through the development process. In this sense, the investigation of the innovation enabled by the collaboration with external sources of knowledge thanks to the complexity lens takes into account the property of emergence of new combinations or interactions [16]. Moreover, the adoption of the complexity lens allows to better evaluate the transformational patterns affecting the development of innovation in an open approach enhanced by nonlinear interactions between different actors. For example, Yun et al. [17] show that collaboration affect the innovation performance of an organization with a nonlinear u-shaped relation.

The willingness to leverage on external sources of knowledge requires enabling connections that widen the potential to realize new business opportunities [18]. In the perspective of complex systems, these connections result in an interdependence where the actors are linked in a mutual interrelationship that affects the respective behaviors.

The interaction with external sources of innovation is characterized by a high degree of diversity, as there are different players, in different interactions, within different institutional contexts and operating according to different norms [2]. The level of variety is also reflected in the highly skilled personnel required in the innovation process. Moreover, the environment in which innovation is developed is characterized by a growth or variety and diversity [14]. Therefore, another key dimension of complexity when dealing with open innovation is the variety.

With the aim of fostering spontaneous forms of coordination for innovation and meeting the shared goals, organizations are required to enable greater autonomy and creativity $[3,12]$ among these different actors. A key capability is then taking advantage of the emergence of these dynamics through an active, deliberate management of them [5]. Indeed, the innovation capability of an organization - and a network of organizations-is strictly linked to its knowledge management and organizational learning [11], which derives from the interaction of autonomous agents characterized by their own norms, beliefs, values, and assumptions [1]. To sum up, the complexity of the open innovation process should consider the property of autonomy.

Basing on this analysis of the literature, we summarized the key features of innovation at the interface between the complexity science and the open innovation perspective as: emergence, nonlinear interaction, interdependence, variety, and autonomy.

\subsection{The Start-Ups' Incubator as an Open Innovation Environment}

The Open Innovation paradigm [18] has been demonstrated as being valuable for firms willing to leverage both internal and external sources of knowledge in order to innovate and widen their potential to realize new business opportunities [18]. Among the main mechanisms to enact the opening up of the innovation process, the role of business incubation and venturing has received increasing attention in literature [6,7]. Indeed, business incubators-and in general the organizations supporting the formation and development of early stage ventures-have a key role as innovation intermediaries in respect to the tenant start-ups $[19,20]$.

Hausberg and Korreck [9] argue that Open Innovation represents a promising theoretical lens in understanding the determinants and implications of business incubators. This kind of infrastructure sustains the creation and growth of new entrepreneurial teams by offering them access to purposive flows of knowledge and a supportive environment for experimentation and interdependence and, therefore, learning from the integration of this knowledge into the development of their business [21-23]. Indeed, an early involvement within the market dynamics can provide an important value to start-up teams for learning, creating partnerships and better developing the potential business, with the final aim of reducing the market and technical uncertainty [24] and accessing to knowledge networks and interorganizational networks [23]. In this sense, they are a key enabler in enabling the opening up of the innovation pathway to external sources of knowledge by the new ventures [19]. They close the distance between the innovation developed by the start-up and the 
market, enabling then a higher open innovation and firm performance [17]. Moreover, the incubators stimulate innovation and entrepreneurship processes in the regions where they are located [25].

Beyond the provision of basic services and facilities, business support services and networking activities (i.e., the intangible aspects) are gaining relevance in the business models of incubators $[9,20]$. Connections and knowledge-intensive services opportunities are identified and built both inside and outside the incubator's boundaries [20,25]. Business incubators provide an environment where tenant start-up teams can leverage on linkages with experienced entrepreneurs, other start-up teams, professionals specialized in intellectual property, strategic and managerial issues, business angels, and other players offering external financing [21]. They allow the new ventures to develop their own innovation strategies by leveraging on external sources when their liabilities associated with being new and small do not allow tangible business opportunities $[20,26]$. Tenant start-ups are able to be established to a bigger scale than without the industry incubator programme [25]. Moreover, factors such as the proximity and the specialization of the business incubator facilitate the exchange of knowledge, experiences, contacts, and resources [27]. Firstly, the close presence of different people willing to innovate within the same facility enables face-to-face meetings and the creation of multiple connections [10]. The co-location of networked agents and the collaboration between them are demonstrated having a crucial role in facilitating knowledge transfer, generating new ideas and transforming them into marketable innovative assets [15]. The business incubators show a commitment in open innovation activities, and at the same time, the tenant start-ups demonstrate an explicit attitude in the co-creation of new ideas with other actors [20]. Secondly, business incubators are usually specialized in the type of services offered and the selection is restricted to start-ups satisfying requirements such as the type of industry and the entrepreneurial team composition. Therefore, common aims and a technical background are a further base for stimulating purposive inflows and outflows of knowledge [24] across the incubator system boundaries.

Basing on these considerations, the strategies of the business incubators which are focused on open innovation and partly bottom-up based [20], and involve different, specialized networks of actors, offer a valuable context to investigate the conditions and the added value of adopting the complexity perspective in the open innovation research field.

\section{Methodology}

With the aim of gaining deeper insights and exploring the micro-foundations of the innovation paths enabled by a business incubator towards tangible business opportunities for its tenant start-ups, we performed a multiple case study research $[28,29]$. In order to capture dynamics and patterns faced by different entrepreneurial teams in numerous development paths, we selected five incubators on the basis of their expertise (all operating from more than fifteen years), their infrastructure and the characteristics of the incubation process (e.g., main objectives and length). From the one side, they all show a clear involvement in start-up teams' growth by offering not only advice and access to networks, but also long incubation programmes (between 1 and 3 years) and in some cases also till the post-incubation phase. Moreover, the selected business incubators focus on innovative start-ups belonging to ICT, digital, and high-tech sectors. This enhance a higher open innovation performance, in terms of width and depth, as it has proved to be strictly linked to the IT content [30]. From the other side, they differ in the infrastructure and in their main objectives. Indeed, the innovation relationship enabled by a different location (e.g., within a context such an university), and the mission mainly focused on mentoring rather than networking, can result in different open innovation performance $[17,30]$. Another variation criterion was the focus on start-ups showing a higher technological base, rather than a cross-disciplinary background, as this influence the mentoring and networking practices for stimulating purposive inflows and outflows of knowledge [24]. Table 1 shows the main characteristics of the five business incubators selected as case studies. 
Table 1. The five start-ups' incubators.

\begin{tabular}{cccccc}
\hline & Incubator A & Incubator B & Incubator C & Incubator D & Incubator E \\
\hline Year of foundation & 2008 & 2005 & 2005 & 1999 & 2000 \\
\hline Number of employees & 15 & 8 & 400 & 20 & 20 \\
\hline $\begin{array}{c}\text { Number of tenant } \\
\text { start-ups }\end{array}$ & 190 & 30 & 64 & 161 & Public \\
\hline $\begin{array}{c}\text { Property } \\
\text { (private/public) }\end{array}$ & Public & Public & Private & Public & Inside \\
\hline $\begin{array}{c}\text { Location/infrastructure } \\
\text { technological } \\
\text { park }\end{array}$ & $\begin{array}{c}\text { Inside } \\
\text { technological } \\
\text { park }\end{array}$ & $\begin{array}{c}\text { Affiliated with } \\
\text { a university }\end{array}$ & $\begin{array}{c}\text { Inside } \\
\text { university }\end{array}$ & university \\
\hline $\begin{array}{c}\text { Main objectives } \\
\text { Mentoring }\end{array}$ & $\begin{array}{c}\text { Mentoring, } \\
\text { financing }\end{array}$ & Venturing & $\begin{array}{c}\text { Networking, } \\
\text { Researching }\end{array}$ & $\begin{array}{c}\text { Networking, } \\
\text { Researching }\end{array}$ \\
\hline Period of incubation & 3 years & 5 years & 3 months & 3 years & 3 years \\
\hline $\begin{array}{c}\text { Scope } \\
\text { (pre/post-incubation) }\end{array}$ & $\begin{array}{c}\text { Pre- and } \\
\text { post-incubation }\end{array}$ & No & No & Post-incubation & Post-incubation \\
\hline
\end{tabular}

The data collection phase included semi-structured interviews and information gathered from archival and publicly available documentation of each incubator. Throughout the research, we focused on the practices and services of the selected incubators that are addressed to the start-ups' growth, supporting the expansion of their innovation process up to an initial maturity. We bounded the scope of the study to the incubation process, i.e., the phases between the so-called pre-incubation period, when start-ups are created and recruited, and the post-incubation or graduation phase, when start-ups reach a level of maturity that allows them to exit the programme and usually develop their business in an independent and self-sustained way. We classified and distinguished the practices and tools of each incubator following the categories of services identified in previous studies $[19,21,22]$ as: physical infrastructure, access to funding streams, experts/entrepreneurs networking, education/workshops, mentorship, and advice. To assure coherence and consistency, we developed an interview protocol, based on the literature review and composed of the following sections:

- General description: aims and mission of the incubator, main features, and stakeholders (including organizations supporting funding);

- Practices and tools to foster collaborative innovation paths; related importance according to incubator's aims.

In order to highlight dynamics and distinguishing features (e.g., variety and autonomy), interrelations and networking patterns observed in the several incubation programs, we asked indirectly for each practice and tool to clarify also with examples the presence of complex dynamics. Subsequently, each of the authors analyses the interview text and tried to fill-in a first draft of the table of intersection between practices and tools and complexity principles. We discussed together if we disagreed and we finally reached a consensus and proposed an examination of the practices in light of the main concepts and principles of complexity theory at the interface with the open innovation perspective. From the cross-case analysis, informed by a pattern-matching approach [28], we derived a theoretically and empirically grounded framework that categorizes the practices and activities of business incubators as simple rules to support the innovation processes (and their management) of the tenant start-ups.

\section{Results}

The empirical analyses of the five case studies revealed recurring features in the practices and services for supporting the innovation process of start-ups toward the maturity phase. Table 2 shows the open innovation services and practices of the five business incubators. 
Focusing on the physical infrastructure, all cases demonstrate the availability of offices to allow the entrepreneurial teams developing their own business, while shared facilities and co-working spaces are less present. This limitation is overcome by the location in a wider space, such as an university or a technological park, where the entrepreneurial teams get in touch with other kind of professional roles and businesses. Despite the different focuses and type of sector of the tenant start-ups, incubators B and D provide an ICT infrastructure (ICT tools) which allows deepening the technical features of the product or service delivered and the type of partners to enter in relation with.

The services enabling access to different funding sources are many and are targeted to a wide portfolio of funds, both public and private. This choice reflects in the opportunity to benefit from multiple potential paths for seed investments to further develop an innovation and open to broader networks of innovation actors to collaborate with. The opportunity of direct investment and provision of funding support is guaranteed by the incubators that are based in institutions that are not universities (i.e., incubator A, B, and C), when there is the opportunity to benefit also from private investments and not only available sources (such as the facilities and financial advice by the present human resources).

In addition, all the incubation programmes are targeted to provide access to dedicated networks. They all show practices aimed to provide to the tenant start-ups the basic tools to self-organize in an environment where the inclusion into several types of networks allows frequent contacts and in-depth meetings with experts and innovative people (such as the other entrepreneurial teams). Innovative kind of networks have been introduced throughout the evolution of the incubation programmes, also after the suggestions by the start-up teams and the emergence of new networks of contacts. These include, for example, the Erasmus for entrepreneurs (incubator B and E), group training (incubator C), and the development of platforms to expand the number of opportunities to get in touch with experts and other entrepreneurs (incubator E). Moreover, some incubators rely on the internal networks of start-ups, in distinct stages of growth and also involved in different programmes, to share knowledge and favor co-located networks through informal networking (e.g., incubators C, D, and E). Others try to extend the internal networks to a global dimension, by enabling collaborations with the foreign offices.

Services of education and workshops seem to be the ones mostly linked to the type of incubation programme, as they are mainly focused on the business issues in the public incubators (i.e., A, B, E, excluding $\mathrm{D}$ as it does not offer specific courses rather focuses mainly on mentoring and researching). Conversely, the incubator C-the only private one-offers innovative workshops and educational models such as campus, summer programs, and laboratories that enable the increase of the potential innovation relationships and development paths thanks to the day-by-day relations between the experts of the incubator and the tenant teams.

Finally, focusing on the mentorship and advice, some incubators aim to provide less structured environments with the provision of focused resources and expertise while accessing to networks with a wider scope. For example, they facilitate meetings with experts to improve the entrepreneurial ideas both from a technical point of view (e.g., software development) and on economic and business issues (e.g., incubator $\mathrm{C}$ has access to industry and technological partners). 
Table 2. Open Innovation services and practices in the five business incubators.

\begin{tabular}{|c|c|c|c|c|c|}
\hline SERVICES & Incubator $\mathbf{A}$ & Incubator B & Incubator C & Incubator D & Incubator $\mathrm{E}$ \\
\hline Physical infrastructure & $\begin{array}{l}\text { Offices } \\
\text { - Possibility to use shared tools } \\
\text { and common spaces }\end{array}$ & $\begin{array}{l}\text { - Offices } \\
\text { - ICT infrastructures (use of } \\
\text { ICT tools) }\end{array}$ & 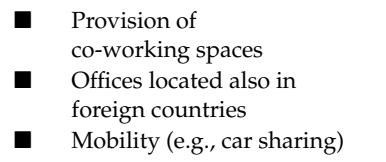 & $\begin{array}{ll}\text { a } & \text { Offices } \\
\text { a } & \text { Labs } \\
\text { - ICT infrastructures (use of } \\
\text { ICT tools) }\end{array}$ & $\begin{array}{l}\text { Offices } \\
\text { - Shared facilities (co-working } \\
\text { spaces, flexible and scalable } \\
\text { spaces, meeting rooms, and } \\
\text { relax spaces) }\end{array}$ \\
\hline Access to funding streams & $\begin{array}{l}\text { - } \begin{array}{l}\text { Direct investment of public } \\
\text { dedicated funds }\end{array} \\
\text { - Dedicated agreements } \\
\text { with banks } \\
\text { - Tax and legal advice } \\
\text { - Financial advice: mentorship } \\
\text { and meetings with experts to } \\
\text { define sources for funding }\end{array}$ & $\begin{array}{l}\text { - Public funding presentations } \\
\text { - Provision of financial support } \\
\text { - Financial advice: meetings with } \\
\text { experts to define sources } \\
\text { for funding } \\
\text { - Assistance for funds rising }\end{array}$ & $\begin{array}{l}\text { - Direct investment } \\
\text { Investment seed } \\
\text { - Contacts with potential } \\
\text { investors, i.e., business angels } \\
\text { and venture capitalists } \\
\text { - Provision of seed } \\
\text { investments, dedicated to the } \\
\text { idea definition, the product } \\
\text { validation and the } \\
\text { market tests }\end{array}$ & $\begin{array}{l}\text { - Collection of seed funds } \\
\text { - Dedicated agreements } \\
\text { with banks } \\
\text { - Dedicated agreements with } \\
\text { business angels and } \\
\text { venture capitals } \\
\text { - Public funding presentations } \\
\text { - Financial advice: mentorship } \\
\text { about the financing strategy }\end{array}$ & $\begin{array}{l}\text { - Corporate venturing } \\
\text { - Corporate spin offs } \\
\text { - Specific challenges for } \\
\text { digitalization by companies } \\
\text { (e.g., Vodafone) } \\
\text { - Financial advice: mentorship } \\
\text { about the financing strategy }\end{array}$ \\
\hline $\begin{array}{l}\text { Experts/Entrepreneurs } \\
\text { networking }\end{array}$ & $\begin{array}{l}\text { - Presence in a scientific and } \\
\text { technological park } \\
\text { - Technical advice } \\
\text { - Technical analysis to validate } \\
\text { the innovative features of the } \\
\text { entrepreneurial idea }\end{array}$ & $\begin{array}{l}\text { - Presence in a scientific and } \\
\text { technological park } \\
\text { Erasmus for Entrepreneurs: } \\
\text { programme of exchange of } \\
\text { entrepreneurs in Europe to favour } \\
\text { learning by doing } \\
\text { - Assistance for partner search } \\
\text { - Technical advice: meetings with } \\
\text { experts to improve the idea from a } \\
\text { technical point of view } \\
\text { Economic and business advice: } \\
\text { Meetings with experts to improve } \\
\text { the entrepreneurial idea as regards } \\
\text { business administration, } \\
\text { innovation, technological transfer, } \\
\text { IPR, and project management }\end{array}$ & $\begin{array}{ll}\text { - Affiliation with the local } \\
\text { university and its spin-offs } \\
\text { - Frequent networking } \\
\text { with entrepreneurs } \\
\text { - Informal exchange of } \\
\text { knowledge (storming pizza) } \\
\text { - Demo day, demo night } \\
\text { - Group training } \\
\text { - International networking } \\
\text { (e.g., GAN network) }\end{array}$ & 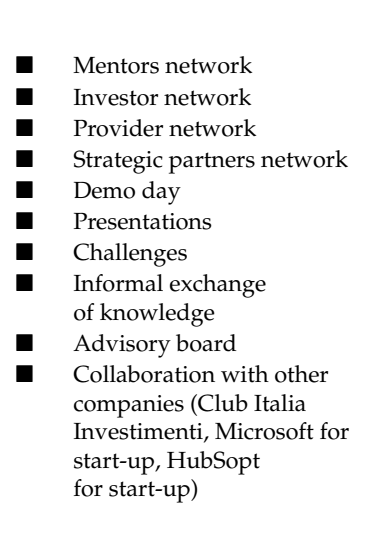 & $\begin{array}{ll}\text { - } & \text { Observatory about start-ups } \\
\text { (Start-up Intelligence) } \\
\text { - Challenges around technology } \\
\text { (Hackathon) } \\
\text { - Start-up scouting \& } \\
\text { Innovation Consultancy } \\
\text { - Call for Ideas } \\
\text { a } \\
\text { Tailored Start up } \\
\text { Erasmus for young entrepreneurs } \\
\text { - Platform for business matching } \\
\text { (d!economy) } \\
\text { - Platform for future technology } \\
\text { matching (d!tech) } \\
\text { - Platform for workshops and } \\
\text { conferences on digital business } \\
\text { (d!talks) } \\
\text { - Platform for events and } \\
\text { networking (d!campus) }\end{array}$ \\
\hline
\end{tabular}


Table 2. Cont

\begin{tabular}{|c|c|c|c|c|c|}
\hline SERVICES & Incubator $\mathbf{A}$ & Incubator B & Incubator C & Incubator D & Incubator $\mathrm{E}$ \\
\hline Education/workshops & $\begin{array}{l}\text { - Business planning courses } \\
\text { and seminars } \\
\text { - Participation to public and } \\
\text { private events and seminars } \\
\text { organized by the } \\
\text { scientific park } \\
\text { - Dedicated workshops }\end{array}$ & $\begin{array}{l}\text { Business planning courses and } \\
\text { seminars and advice on how to develop } \\
\text { a business plan }\end{array}$ & $\begin{array}{l}\text { - Courses on strategic issues, } \\
\text { economic and financial } \\
\text { planning, and logistics } \\
\text { - Campus related to schools } \\
\text { (design school, professional } \\
\text { school, and } \\
\text { h-international school) } \\
\text { - Path for students in digital } \\
\text { management with } \\
\text { internships in companies) } \\
\text { - Laboratories for young } \\
\text { people and students } \\
\text { - Summer programs for } \\
\text { digitalization of students } \\
\text { - Masters in digitalization }\end{array}$ & n.a. & 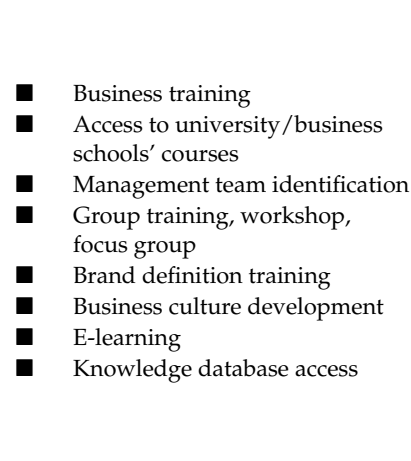 \\
\hline Mentorship and advice & 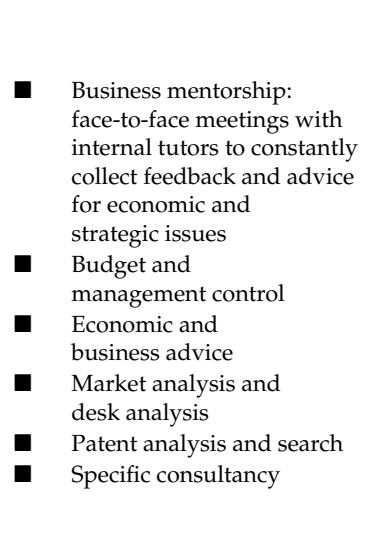 & $\begin{array}{l}\text { Business mentorship: face-to-face } \\
\text { meetings with internal tutors (and } \\
\text { eventual external consultant) to } \\
\text { constantly collect feedback and } \\
\text { advice for economic and } \\
\text { strategic issues } \\
\text { Technical mentorship: face-to-face } \\
\text { meetings with internal tutors (and } \\
\text { eventual external consultant) in } \\
\text { order to constantly collect feedback } \\
\text { and advice for technical issues } \\
\text { related to idea } \\
\text { Presence of a technical scientific } \\
\text { committee to evaluate the business } \\
\text { plan from a technical and business } \\
\text { point of view }\end{array}$ & $\begin{array}{ll}\text { - } & \text { Industry partner } \\
\text { 口 } & \text { Accelerator team } \\
\text { 口 } & \text { Tech Partner } \\
\text { - GAN (Global Accelerator } \\
\text { Network) service } \\
\text { - } \\
\text { Mentorship \& workshop }\end{array}$ & $\begin{array}{l}\text { - Mentorship } \\
\text { - Specialized tutor dedicated to } \\
\text { every single company }\end{array}$ & $\begin{array}{ll}\text { - } & \text { Scouting } \\
\text { - } & \text { Tutorship } \\
\text { - } & \text { Mentorship } \\
\text { - } & \text { Consultancy } \\
\text { - Specific scouting on customer } \\
\text { experience (e.g., AVIVA } \\
\text { Customer Innovation Award) } \\
\text { - Challenges with companies (e.g., } \\
\text { Unlock Your ability with Energy } \\
\text { industry companies) } \\
\text { - Legal advice } \\
\text { - } \text { Marketing assistance } \\
\text { - Research of customers and } \\
\text { - Partners assistance } \\
\text { - } \text { Promotion with PRs } \\
\text { - Cechnological assistance } \\
\text { - } \text { Bustomer relations management } \\
\text { Business planning }\end{array}$ \\
\hline
\end{tabular}




\section{Discussion}

All the start-ups' incubators selected for the study show that the provision of tools and services to sustain the innovation paths of tenant start-ups' results in an organic development of self-organizing dynamics and emergent properties [14]. They all act as knowledge hubs by providing connections to internal and external networks of different types of sources, such as universities and research institutes, funding sources (e.g., business angels and venture capitalists), and incubators in other regions [25], thanks to the provision of multiple opportunities and services that can vary in terms of focus and width according to their nature.

The incubators provide to their tenant start-ups several share assets, both tangible and intangible, in various configurations and in a complementary way. Along with this line, incubators should provide all the types of practices to create awareness on the possible paths to be undertaken when start-ups are looking for reducing uncertainty, increasing diversity or number of linkages in the future market. This is in line with results from authors of a previous study [8], which show that start-ups located in the more recent incubation programmes make full use of the service portfolio.

Business incubators create an institutional environment for a continuous improvement, with the goal of eliminating possible barriers and provide the incentives to access to business networks, more collaboration opportunities and intensive-and even unintended-knowledge spillovers [15] across and along the incubation process. These can also result in innovative and more varied services to be provided in a portfolio that can be further enriched thanks to the feedback received and the unintended patterns that emerged throughout the evolution of the incubation programmes.

Table 3 shows the relationship of open innovation practices with complexity principles in the context of the selected start-ups' incubators. While it was not possible to distinguish among the width and depth of the open innovation enabled by the different incubators according to their nature or aims [17], we can argue that some categories of open innovation services and practices stimulated more principles of complexity, in particular:

- Physical infrastructure: principles of emergence, autonomy, and interdependence

- Access to funding streams: principles of autonomy and interdependence

- Experts/Entrepreneurs networking: all complexity principles identified

- Education/workshops: principles of variety and autonomy

- Mentorship and advice: principles of autonomy and nonlinear interaction

Focusing on the physical infrastructure, the availability of offices and ICT tools mainly support the entrepreneurial teams to develop their own business following as autonomous agents their own norms, beliefs, values, and assumptions [1], while shared facilities such as co-working spaces further stimulate mutual interrelationships and the emergence of new collective behaviors. This is true also for the funding support, as the different types of funding and investments result differently in guaranteeing the growth of an autonomous venture (e.g., in the case of seed investments and targeted financial support) or interdependent start-ups that continuously leverage on broader networks of innovation actors to collaborate with. Indeed, the provision of financial resources represents a key foundation for the innovation process as also financial capital contributes as a systemic resource [12].

Confirming the richness of the innovation processes in industrial districts [1] or in the emergence of the creativity process [3], practices, and services enabling networking in the incubation process through different relationships, with different width and depth, and with different kinds of actors, results in all the complexity principles identified in literature. 
Table 3. Complexity principles reinforced by open innovation services and practices in the business incubators.

\begin{tabular}{|c|c|c|c|c|c|}
\hline & & & COMPLEXITY PRINCIPLES & & \\
\hline SERVICES & Emergence & Nonlinear interaction & Interdependence & Variety & Autonomy \\
\hline $\begin{array}{l}\text { Provision of office and } \\
\text { co-working space }\end{array}$ & - Shared facilities & & $\begin{array}{l}\text { Provision of co-working spaces } \\
\text { - Offices located also in foreign countries } \\
\text { - Shared facilities } \\
\text { - Labs }\end{array}$ & & $\begin{array}{ll}\text { - } & \text { Possibility to use tools } \\
\text { and spaces } \\
\text { - Offices } \\
\text { - Labs } \\
\text { ICT infrastructures } \\
\text { - } \text { Mobility (e.g., car sharing) }\end{array}$ \\
\hline Access to funding streams & & & 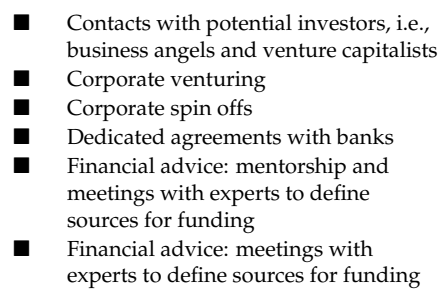 & & $\begin{array}{ll}\text { - } & \text { Direct investment } \\
\text { - } & \text { Seed investments } \\
\text { Tax and legal advice } \\
\text { - } \\
\text { - Public funding presentations } \\
\text { Provision of financial support } \\
\text { - } & \text { Assistance for funds rising } \\
\text { - Financial advice }\end{array}$ \\
\hline $\begin{array}{l}\text { Experts/Entrepreneurs } \\
\text { networking }\end{array}$ & $\begin{array}{l}\text { - Presence in a scientific and } \\
\text { technological park } \\
\text { - Technical analysis to validate } \\
\text { the innovative features of the } \\
\text { entrepreneurial idea } \\
\text { - Demo day } \\
\text { - Presentations } \\
\text { - Challenges } \\
\text { - Call for Ideas }\end{array}$ & $\begin{array}{ll}\text { - } & \text { Frequent networking } \\
\text { with entrepreneurs } \\
\text { - } \\
\text { Affiliation with the local } \\
\text { university and its spin-offs } \\
\text { a } \\
\text { Erasmus for Entrepreneurs } \\
\text { Informal exchange } \\
\text { of knowledge } \\
\text { Challenges } \\
\text { - Collaboration with } \\
\text { other companies } \\
\text { - Call for Ideas }\end{array}$ & 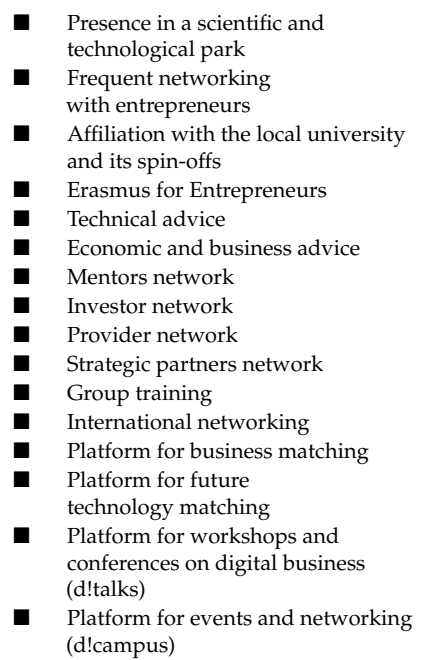 & 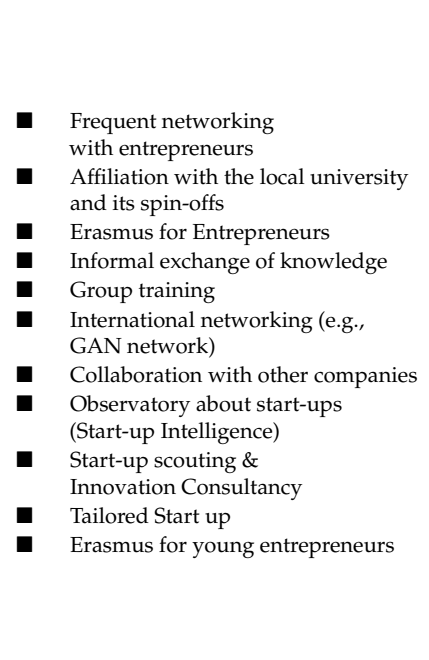 & $\begin{array}{l}\text { - Presence in a scientific and } \\
\text { technological park } \\
\text { - Assistance for partner search } \\
\text { - Technical advice } \\
\text { - Advisory board }\end{array}$ \\
\hline
\end{tabular}


Table 3. Cont

\begin{tabular}{|c|c|c|c|c|c|}
\hline \multirow[b]{2}{*}{ SERVICES } & \multicolumn{4}{|c|}{ COMPLEXITY PRINCIPLES } & \multirow[b]{2}{*}{ Autonomy } \\
\hline & Emergence & Nonlinear interaction & Interdependence & Variety & \\
\hline Mentorship and advice & & 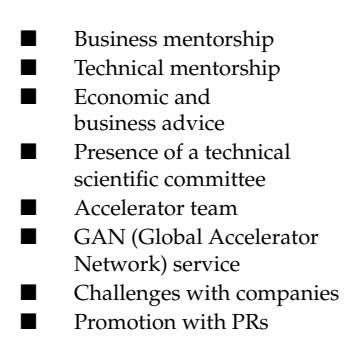 & & & 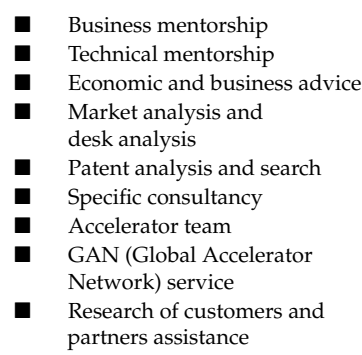 \\
\hline Education/workshops & & & & $\begin{array}{l}\text { - Business planning courses } \\
\text { and seminars } \\
\text { - Participation to public and private } \\
\text { events and seminars organized by } \\
\text { the scientific park } \\
\text { Dedicated workshops } \\
\text { Campus related to schools } \\
\text { - Path for students (students in digital } \\
\text { management with internships } \\
\text { in companies) } \\
\text { - Laboratories for young people } \\
\text { and students } \\
\text { - Summer programs for digitalization } \\
\text { of students } \\
\text { - Masters in digitalization }\end{array}$ & 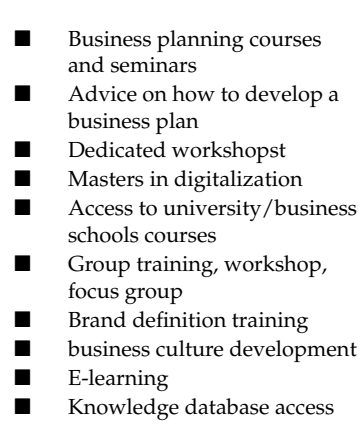 \\
\hline
\end{tabular}


Overall, the results allow conceptualizing the incubation program as a networked process embedded in a complex system whose boundaries are determined by the interactions between multiple different stakeholders. They offer evidence that the practices of the incubators do have an impact on the pathways of the tenant start-ups to the initial maturity as they are framed to enable both the network connections and the entrepreneurial skills. The business incubators create the conditions for innovative and collaborative networks as simple rules in order to stimulate their systematization at a higher scale, once the start-ups end the incubation program is enabled to look for the creation and diffusion of innovation in higher level networks. Therefore, start-ups' incubators can be framed as environments "where a rich texture of entrepreneurship and technological constraints allows the conversion of energy (in the form of intellectual creativity and funding)" [14] (p. 462) into innovative products and services.

The nonlinear interactions are also observed in the internal networks with the incubators' mentors. These interactions at smaller scale are built through specific advice and consultancy that conjugate in a bottom-up effort the focused resources and expertise while accessing to networks with a wider scope. Indeed, the more recent generation of business incubators is mainly focusing on the provision of the access to technological, professional, and financial networks, and in general, the sources of assets and knowledge beyond their boundaries [8], and this can be explained in the light of the growing complexity of the business and social world of nowadays. Moreover, they foster the principle of variety by providing focused education and training, also reflecting the differences in the way they run their services [10].

The practices of the incubators should then be framed as simple, micro-rules in order to foster the needed knowledge and innovation process of new ventures to emerge, evolve 'more fully' and persist in the long term [5]. In this way, this kind of infrastructure needs to re-examine its practices and the mechanisms they foster in tenant start-ups from a complexity theory perspective in order to manage and capitalize [3] on the emergent innovation processes.

\section{Conclusions}

This paper presents a novel perspective on roles and paths in open innovation as it adopts the complexity concepts in the particular context of business incubators, conceptualized as a complex system where start-ups benefit from the access to multiple dedicated networks for advice and access to resources and knowledge sources. It contributes to the debate on the application of complexity principles to the open innovation research field by studying the conditions-in this case, the practices of the business incubators that enable a network-based innovation development for the creation of new value $[5,23]$. Results show how practices and services aimed to foster open innovation can enable one or more complexity principles if they cover a wider portfolio that encompasses infrastructure, business support services, and networking [8].

From the complexity theory perspective, the principle of emergence is better enabled by the provision of physical infrastructure and the networking; the nonlinear interactions among the innovation actors by the networking and mentorship; the interdependence among the entrepreneurial teams and the other sources of knowledge by the physical infrastructure, the access to funding streams, and the networking; the variety of their features and relationships by networking and education; and their autonomy by all the categories of services included in the portfolio.

From the open innovation perspective, the study of the concepts of variety, nonlinear interactions, interdependence, autonomy, emergence in the actors, practices, and process of open innovation allows to evaluate the development of unintended paths or outcomes that can enrich the relationships with external sources of knowledge with valuable components.

Finally, this paper contributes to the literature on business incubators by providing a new perspective for analyzing their practices [21], i.e., the interface between principles of complexity theory and the open innovation process. 
From the practitioners' point of view, this study provides some guidelines for business incubators, and in general institutions and programmes supporting new ventures growth, to address their activities and services in an effective way. These should be maintained in a simple, focused manner to make the tenant start-ups improving their entrepreneurial skills, increasing the linkages with several knowledge sources and taking advantage of the emergence of processes for sustainable growth [5] beyond the incubation programme. Additionally, the start-up teams should leverage on the created micro-mechanisms and adapt them to the market conditions to better sustain their growth and possible survival. Synergies and innovation patterns among start-ups and supporting institutions are indeed a valuable mean to promote entrepreneurship and economic growth $[5,21]$.

Despite the case study methodology has been proved adequate when considering the complexity perspective within the innovation research [16], the obtained results could be integrated by a quantitative research where operationalizing the practices of the incubators in terms of width and depth [30] in enabling the complexity concepts and the mediating variables. The latter ones include, for example, the variation among the different principles of complexity and their prevalence (e.g., more variety or nonlinear interactions affect the open innovation performance) basing on the contextual conditions not considered in the analysis (e.g., location and objectives of the start-ups' incubator), the types of entrepreneurial teams accepted in the incubation programmes, and the temporal dynamics throughout the innovation pathways, e.g., recurring patterns during the development of specific activities that involve the overall system. These factors can be then operationalized in moderating variables influencing the prosecution of the start-up growth from the incubation programme to their maturity within the market.

Author Contributions: Conceptualization, all authors; Methodology, C.B. and E.P.; Data curation, C.B. and E.P.; Supervision, A.F.D.T.

Funding: The publishing fee of this paper was supported by the DGIST R\&D Program of the Ministry of Science, Technology and ICT (DGIST-18-IT-01).

Conflicts of Interest: The authors declare no conflicts of interest.

\section{References}

1. Albino, V.; Carbonara, N.; Giannoccaro, I. Innovation in industrial districts: An agent-based simulation model. Int. J. Prod. Econ. 2006, 104, 30-45. [CrossRef]

2. Goldstein, J.; Hazy, J.K.; Silberstang, J. A Complexity Science Model of Social Innovation in Social Enterprise. J. Soc. Entrep. 2010, 1, 101-125. [CrossRef]

3. De Toni, A.F.; Biotto, G.; Battistella, C. Organizational design drivers to enable emergent creativity in web-based communities. Learn. Org. 2012, 19, 335-349. [CrossRef]

4. Jarvenpaa, S.L.; Wernick, A. Paradoxical tensions in open innovation networks. Eur. J. Innov. Manag. 2011, 14, 521-548. [CrossRef]

5. Dougherty, D. Taking advantage of emergence for complex innovation eco-systems. J. Open Innov. Technol. Mark. Complex. 2017, 3. [CrossRef]

6. Chesbrough, H.; Brunswicker, S. A Fad or a Phenomenon? The Adoption of Open Innovation Practices in Large Firms. Res. Technol. Manag. 2014, 57, 16-25.

7. Van de Vrande, V.; De Jong, J.P.J.; Vanhaverbeke, W.; De Rochemont, M. Open innovation in SMEs: Trends, motives and management challenges. Technovation 2009, 29, 423-437. [CrossRef]

8. Bruneel, J.; Ratinho, T.; Clarysse, B.; Groen, A. The Evolution of Business Incubators: Comparing demand and supply of business incubation services across different incubator generations. Technovation 2012, 32, 110-121. [CrossRef]

9. Hausberg, J.; Korreck, S. Business Incubators and Accelerators: A Co-Citation Analysis-Based, Systematic Literature Review. J. Technol. Transf. 2018. [CrossRef]

10. Grimaldi, R.; Grandi, A. Business incubators and new venture creation: An assessment of incubating models. Technovation 2005, 25, 111-121. [CrossRef] 
11. Chapman, R.; Hyland, P. Complexity and learning behaviors in product innovation. Technovation 2004, 24, 553-561. [CrossRef]

12. Sun, J.; Wu, S.; Yang, K. An ecosystemic framework for business sustainability. Bus. Horiz. 2018, 61, 59-72. [CrossRef]

13. Johannessen, S.; Aasen, T.M.B. Exploring innovation processes from a complexity perspective. Part I: Theoretical and methodological approach. Int. J. Learn. Chang. 2007, 2, 434-446. [CrossRef]

14. Andriani, P. Complexity and innovation. In The SAGE Handbook of Complexity and Management; Allen, P., Maguire, S., McKelvey, B., Eds.; SAGE Publications: Thousand Oaks, CA, USA, 2011; pp. 454-470.

15. Russell, M.G.; Smorodinskaya, N.V. Leveraging complexity for ecosystemic innovation. Technol. Forecast. Soc. Chang. 2018. [CrossRef]

16. Poutanen, P.; Soliman, W.; Ståhle, P. The complexity of innovation: An assessment and review of the complexity perspective. Eur. J. Innov. Manag. 2016, 19, 189-213. [CrossRef]

17. Yun, J.J.; Jeong, E.-S.; Lee, C.; Park, J.; Zhao, X. Effect of Distance on Open Innovation: Differences among Institutions According to Patent Citation and Reference. Sustainability 2017, 9, 1478. [CrossRef]

18. Chesbrough, H.W. Open Innovation: The New Imperative for Creating and Profiting from Technology; Harvard Business School Press: Boston, MA, USA, 2003.

19. Battistella, C.; De Toni, A.F.; Pessot, E. Open accelerators for start-ups success: A case study. Eur. J. Innov. Manag. 2017, 20, 80-111. [CrossRef]

20. Macchi, M.; Rizzo, U.; Ramaciotti, L. From services dealers to innovation brokers: How open innovation paradigm affects incubator activities. Evidence from Italy. J. Intellect. Cap. 2014, 15, 554-575. [CrossRef]

21. Blok, V.; Thijssen, S.; Pascucci, S. Understanding Management Practices in Business Incubators: Empirical Evidence of the Factors Impacting the Incubation Process. Int. J. Innov. Technol. Manag. 2017, 14, 1750023. [CrossRef]

22. Bøllingtoft, A. The bottom-up business incubator: Leverage to networking and cooperation practices in a self-generated, entrepreneurial-enabled environment. Technovation 2012, 32, 304-315. [CrossRef]

23. Gupta, A.K.; Dey, A.R.; Shinde, C.; Mahanta, H.; Patel, C.; Patel, R.; Ganesham, P. Theory of open inclusive innovation for reciprocal, responsive and respectful outcomes: Coping creatively with climatic and institutional risks. J. Open Innov. Technol. Mark. Complex. 2016, 2. [CrossRef]

24. Chesbrough, H.; Vanhaverbeke, W.; West, J. Open Innovation: Researching a New Paradigm; Oxford University Press: Oxford, UK, 2006.

25. Clausen, T.; Rasmussen, E. Open innovation policy through intermediaries: The industry incubator programme in Norway. Technol. Anal. Strateg. Manag. 2011, 23, 75-85. [CrossRef]

26. Soetanto, D.P.; Jack, S.L. Business Incubators and the Networks of Technology-Based Firms. J. Technol. Transf. 2013, 38, 432-453. [CrossRef]

27. Cooke, P. Complex spaces: Global innovation networks \& territorial innovation systems in information \& communication technologies. J. Open Innov. Technol. Mark. Complex. 2017, 3. [CrossRef]

28. Voss, C.; Tsikriktsis, N.; Frohlich, M. Case research in operations management. Int. J. Oper. Prod. Manag. 2002, 22, 195-219. [CrossRef]

29. Yin, R.K. Case Study Research: Design and Methods, 5th ed.; Sage Publications: Thousand Oaks, CA, USA, 2013.

30. Yun, J.J.; Avvari, M.V.; Jeong, E.-S.; Lim, D.-W. Introduction of an objective model to measure open innovation and its application to the information technology convergence sector. Int. J. Technol. Policy Manag. 2014, 14, 383-400. [CrossRef]

(C) 2018 by the authors. Licensee MDPI, Basel, Switzerland. This article is an open access article distributed under the terms and conditions of the Creative Commons Attribution (CC BY) license (http://creativecommons.org/licenses/by/4.0/). 